\title{
Violência Civilizacional e Colonial no Olhar de Frantz Fanon e Sigmund Freud
}

\author{
Lassana Danfá ${ }^{1}$ \\ ${ }^{1}$ Universidade Federal de Pernambuco, PE, Brasil.
}

Resumo: O presente estudo visa discutir a violência na sua relação com o nascimento da civilização e projeto colonial no pensamento de Freud e Fanon. Na obra freudiana, a violência foi abordada a partir das obras: Futuro de uma Ilusão, O Mal-Estar na Civilização, Por Que a Guerra? e Reflexões para os Tempos de Guerra e Morte. E no pensamento fanoniano a partir de Os Condenados da Terra, mais concretamente no capítulo dedicado à violência. A discussão da obra dos autores foi dividida em três momentos. Primeiramente foi discutido o modo como a construção da civilização europeia e a cultura ocidental têm sido marcadas pela violência aos grupos étnicos externos ao Ocidente. No segundo momento, discorre sobre a violência colonial, articulada com a raça, em que a obra de Fanon teve o seu foco principal. Discute-se ainda, por fim, a "contraviolência" e a violência como meio de se subjetivar diante da subjetividade rechaçada.

Palavras-chave: Violência, Freud, Fanon, Civilização, Raça.

\section{Civilizatory and Colonial Violence from the Standpoint of Frantz Fanon and Sigmund Freud}

\begin{abstract}
This study discusses violence as pertaining to the birth of civilization and colonial project in Freud and Fanon. In Freud's work, violence was approached in the papers: Future of an Illusion and Civilization and its Discontents; Why War? and Refletion on War and Death. Whereas Fanon thoughts are exposed in the book The Condemned of the Earth, most notably in the chapter dedicated to violence. The discussion of the authors' work was divided into three sections, namely: how the construction of European civilization and/or Western culture has been marked by violence to ethnic groups outside the West; colonial violence articulated with race, focus of Fanon's work; and "contraviolence" and violence as a means of self-subjectifying in the face of rejected subjectivity.
\end{abstract}

Keywords: Violence, Freud, Fanon, Civilization, Race.

\section{Violencia Civilizatoria y Colonial bajo la Mirada de Frantz Fanon y Sigmund Freud}

Resumen: El presente estudio tiene como objetivo discutir la violencia en su relación con el nacimiento de la civilización y el proyecto colonial en Freud y Fanon. En el trabajo de Freud, se abordaba la violencia desde las obras: El Porvenir de una Ilusión, El Malestar en la Cultura; ¿Por Qué la Guerra? y De Guerra y Muerte: Temas de Actualidad. Y en el pensamiento fanoniano la obra Los Condenados de la Tierra, pero concretamente en el capítulo dedicado a la violencia. La discusión del trabajo de los autores se dividió en tres momentos. En primer lugar, se ha 
discutido la forma en la cual la construcción de la civilización europea y/o la cultura occidental ha estado marcada por la violencia a los grupos étnicos fuera de Occidente. En segundo trata la violencia colonial, articulada con la raza, en la cual el trabajo de Fanon tenía su enfoque principal. Por último, la "contraviolencia" y la violencia se discuten como un medio de subjetivarse frente a la subjetividad rechazada.

Palabras clave: Violencia, Freud, Fanon, Civilización, Raza.

\section{Introdução}

O presente estudo objetiva discutir a violência e/ou a "contraviolência"1 em Fanon, a partir da obra Os Condenados da Terra, focando principalmente no capítulo "Da violência". Trataremos da violência também em Freud, por meio dos seguintes escritos: Futuro de uma Ilusão; O Mal-Estar na Civilização; Por Que a Guerra? e Reflexões para os Tempos de Guerra e Morte. O artigo propõe, ainda, se debruçar sobre o modo como o processo civilizatório ocidental tem sido marcado pela violência.

Primeiro, é importante destacar a noção de sujeito dos dois pensadores, baseando-se em obra de Bird-Pollan (2015). Freud pensa o sujeito em busca da unidade pré-edipiana perdida, por meio da instauração da autoridade edípica que visa fazer um corte fusional narcísico entre a criança e as figuras paternas. Isto pressupõe a existência de uma figura, atribuída a uma dimensão de completude, com a qual se possa identificar, no primeiro momento, para em seguida se desintegrar dela. Ainda para este autor, a noção do sujeito freudiano é fruto de uma dialética pulsional. Enquanto isso, Fanon parte da noção de sujeito colonial e escravizado, isto é, um sujeito desenraizado, cultural e psiquicamente, em busca de uma relação fusional ou narcísica inexistente. Neste caso, um sujeito sem uma relação pulsional em que as figuras parentais, o outro, as quais possam ser atribuídas dimensões de onipotência (Bird-Pollan, 2015).

Entretanto, diferentemente de Bird-Pollan, há autores, como Jean Laplanche (1993), que problematizam de modo diferente a noção de sujeito em Freud. Laplanche chegou a afirmar tempos depois que a discussão sobre o "sujeito" em Freud não existe enquanto tal como Lacan, por exemplo, tem feito. Segundo ele, Freud não pensou no sujeito para além das categorias com as quais ele trabalhou. De acordo com esta visão, havia em Freud três agentes conjuntos e muitas vezes contraditórios: o id, o ego e o superego.
Onde estaria o sujeito? Laplanche diz que se por sujeito entende-se "agente", ele estaria no momento em que uma dessas instancias predomina. Ou seja, se em um sintoma, por exemplo, predominam as forças do id, pode-se dizer nesse momento que o id é o agente, o sujeito (Laplanche, 1993).

Primeiramente será apresentado a noção da agressividade e violência. Em seguida, a discussão sobre o pensamento de Sigmund Freud e Frantz Fanon acerca da violência constitutivo do ocidente-europeu-cristão e da violência colonial. E por fim, as considerações finais.

Em seu livro Violência e Psicanálise, Jurandir Freyre Costa (1984) demonstrou desacordo com as vertentes que colocam a violência como necessariamente inconsciente. Para este psicanalista, todo ato violento deriva de um desejo ou de motivações, exceto nos casos em que ele é utilizado como mecanismo substituto, situações em que minorias são criadas como bodes expiatórios, comuns nos casos de crises humanas potenciais. Nestes casos, ao outro são imputados os nossos fracassos, os problemas sociais mal resolvidos e outras motivações. Nota-se que mesmo a violência dita irracional tem o seu início atrelado à razão. Assim, enquanto seres humanos, temos predisposições à agressividade, porém, nem todos os atos agressivos são em si violentos. Para que um ato agressivo se transforme em violência, é necessário que haja desejo e motivação. Assim, a violência é manifestação desejada da agressividade. Por sua vez, Clastres (2004) também discorda da ideia instintiva e/ou inconsciente da violência, ao acreditar que qualquer ação violenta tem uma destinação, e, por isso, vem com um desejo embutido nela.

Constata-se, portanto, que "o sujeito violentado (observador externo à situação) percebe no sujeito violentador o desejo de destruição (desejo de morte, desejo de fazer sofrer) que a ação agressiva ganha o significado de ação violenta" (Costa, 1984, p. 30).

${ }^{1}$ Termo empregado por Achille Mbembe (2018) em A crítica da razão negra. 
O autor considera, portanto, que todo ato humano tem subjacente o desejo, o que inclui os atos violentos. Neste sentido, não podem ser considerados ações violentas aquelas que expressam pura manifestação instintiva da agressividade, uma vez que não estão contidas nelas o desejo da destruição. Vimos, por exemplo, que a satisfação da felicidade e o sustento do mercado capitalista foram os desejos que nortearam toda a violência europeia contra os escravizados e os colonizados.

$\mathrm{Na}$ ótica freudiana (Freud, 1974b), a violência civilizacional se caracteriza pelo uso da força por meio da autorização da comunidade, do direito e da ética construídos pela ação de toda a comunidade. Assim, a força bruta, centrada em um único indivíduo, se dissipou com o avanço da civilização. Neste sentido, os atos violentos passam a ser mediadas pelo intelecto e pela tecnologia (Freud, 1974b). Ou seja, a modernidade é marcada pelo primado do direito e da lei em oposição à autoridade individual da era das grandes monarcas. O que significa dizer que o direito pode ser utilizado por uma minoria dominante ao seu serviço, distribuindo poderes para se protegerem entre si, e em certos casos excluindo e violentando os outros. E, por sua vez, a violência pode se apoiar no direito, razão pela qual Freud não compreende a relação entre violência e direito como antíteses, tendo em vista que uma se desenvolve no outro (Freud, 1974b). Neste caso, a lei, ou o direito, e a violência operam de forma harmônica.

Por sua vez, Clastres (2004), pensa também a violência na ótica cultural, neste caso, por meio do conceito de etnocídio ${ }^{2}$, na medida em que se trata de uma civilização que nasceu na destruição brutal e sistemática da cultura, pensamento e espírito dos povos não europeus. Para este pensador, isto ocorreu por meio da propaganda enganosa, criando a ilusão de que a os ditos primitivos são maus em suas essências, podendo ser civilizados e moralizados por meio da imposição cultural. O que seria possível por meio do uso da fé cristã, tida como a única capaz de elevar o ser humano à dimensão sublime. Para este autor, o que distingue a capacidade etnocida da Europa da dos outros Estados é o seu uso sem freio. Destaca-se, neste caso, o capitalismo, um meio de exploração sistemática em uma escala mundial por meio da aplicação da máquina destrutiva nas formas de referência do autóctone.
Na mesma ótica cultural e/ou civilizacional, a violência pode se manifestar em ato e em forma ideológica, e/ou simbólica, impositiva. É nesta perspectiva que Bourdieu e Passeron, citados por Rosendo (2009), consideram que toda a ação pedagógica é em si violenta, na medida em que implica a imposição, da maneira arbitrária, de um modelo cultural ou antropológico. Os autores ressaltam que a força da ação pedagógica reside na capacidade de dominar as estruturas simbólicas do poder e/ou das posições sociais. Ainda na visão destes pensadores, a ação pedagógica simbolicamente violenta se expressa por meio da reprodução dos ideais da classe dominante, reforçando e multiplicando os modelos dos grupos sociais hegemônicas. Tais grupos exercem sobre os dominados o poder sobre os atos violentos, se colocando, portanto, como os únicos legítimos no exercício da violência via ação pedagógica. Este tipo de violência é marcada pela determinação de formas convencionais, em que alguns padrões são selecionadas em detrimento de outros.

Baseado em Bourdieu e Passeron, citados por Rosendo (2009), Jurandir Freyre Costa (1984) acredita que qualquer que seja civilização, para se constituir, necessita selecionar arbitrariamente significações por meio da imposição de significados pedagogicamente. Para o autor, a imposição cultural de modelo e a sua consequente reprodução é, em si, violenta. São inequívocas, portanto, as ações semelhantes; basta lembrarmos a forma como o ocidente europeu, por meio da sobreposição de uma civilização, de um tipo "ideal” do homem (o branco) e de certos preceitos morais aos outros povos, fez uso da violência e de assassinatos de forma desenfreada. Dito de outra forma, foi em nome do modelo da branquitude que a civilização ocidente-cristã-europeia foi imposta, invadindo e embrutecendo os povos. Isto contradiz a moral fundante por ela engendrada como, neste caso, "não matarás o outro" Levinas (2004). É também o que o grupo social dominante emprega nas sociedades em diversas sociedades, neste caso, a imposição da branquitude e a negação do corpo e identidade negra. Estamos, portanto, diante de uma civilização que, do ponto de vista da sua estrutura ideológica e simbólica, é em si violenta. $\mathrm{O}$ mesmo acontece quando os grupos sociais

\footnotetext{
${ }^{2}$ Etnocídio é conceituado por Clastres (2004, p. 87) como a "supressão das diferenças culturais julgadas inferiores e más; é a aplicação de um princípio de identificação, de um projeto de redução do outro ao mesmo (o índio amazônico suprimido como outro e reduzido ao mesmo como cidadão brasileiro". Em outras palavras, o etnocídio resultado na dissolução do múltiplo no Um.
} 
dominantes procuram impor aos dominados na sociedade brasileira, por exemplo, modelos de beleza branca, recusando do corpo a ideia da beleza negra por meio da imposição simbólica de um modelo cultural e de padrões da beleza brancos. Jurandir Freire Costa (1984) denomina isto como a dupla violência do homem branco brasileiro para com o negro: abdicar do corpo negro, seguindo os ideais e modelos da branquitude ${ }^{3}$.

Estamos, portanto diante das contradições da civilização, em que mesmo perante os grandes avanços "civilizacionais", o primado da força permanece intacta. É nesse prisma que Fanon pensa a violência, articulando-a com a constituição do ocidente na sua relação com a colonização.

Na visão de Fanon (2005), a escravidão e a descolonização não ocorreram como abalos naturais nos moldes de irrupção vulcânica ou foram produto de uma operação milagrosa, mas sim, aconteceram por meio de imposições violentas. Isto porque elas pressupõem confrontos de duas forças e dois modelos de sujeitos com desejos antagônicos, e que, por conseguinte, provocaram forças violentas. Este fato coloca lado a lado os canhões dos colonizadores e a força que resta dos colonizados. Assim, de um lado, o explorador e, do outro, o emancipado, cujos destinos se encontram em suas próprias mãos. Para o martinicano, existia um mundo de exclusão recíproco entre o colonizado e colonizador que dificultava o diálogo pacífico. É o que levou este pensador a afirmar a impossibilidade da descolonização sem o retorno da violência contra o colonizador, neste caso, a contraviolência, termo cunhado por Achille Mbembe (2018).

A partir dos autores apresentados, pretendo propor a dupla violência: a civilizacional e a colonial. A primeira se manifesta por meio da imposição cultural e da negação identitária de grupos sociais subjugados ou marginalizados. Trata-se do início da civilização ocidente-europeu por meio do exercício da violência contra os povos não europeus e da rejeição e desvalorização de identidades não branco-europeias. A segunda se expressa por meio da imposição violenta e colonizadora de um modelo única da civilização, por via da invasão e das atrocidades.

\section{Violência e nascimento da civilização}

Em suas obras Futuro de uma Ilusãoe OMal-Estar na Civilização, Freud (1927/1974b) considera a civilização sob dois prismas: a) o domínio da habilidade humana de dominar a natureza, se apropriando das riquezas naturais em prol das necessidades humanas; e b) o ajustamento das relações entre os seres humanos, principalmente no que concerne à distribuição das riquezas e/ou recursos naturais transformados com ajuda do intelecto (Freud, 1927/1974b). Freud já havia apontado falhas e imperfeições nos ideais da civilização, possibilitando a inferência de duas problemáticas. A primeira, para o domínio da natureza: a cultura ocidental amparada pelos instrumentos de violência e da tese da moral cristã-ocidental precisou brutalizar, pilhar e assaltar povos não ocidentais, arrancando-os das suas raízes. A título de exemplo, temos a invasão atroz aos negro-africanos, indígenas, latino-americanos e asiáticos. Um tipo de violência que denomino aqui como "violência civilizacional". Ou seja, uma forma de violentar os outros não ocidentais com argumentos civilizatórios e moralizadores, tais como "salvar a alma negra dos pecados". Aliás, para Clastres (2004), uma das justificativas para invasão dos outros povos tidos como primitivos deve-se à vinculação destes à infelicidade constitutiva da vida primitiva. Ou seja, a visão do mundo primitivo como planeta das misérias. O mesmo ocorreu também, por meio das descrições insuficientes e preconceituosas, que atrelam ao africano o primitivismo e aos orientais o mistério. Ou seja, os não-nós precisam ser subjugados e violentados para que possam civilizar-se e, por conseguinte, sair da infelicidade "natural" (Said, 1995).

A segunda problemática que o conceito destaca diz respeito a criação de vínculos "harmônicos" entre os cidadãos branco-europeus, causando desarmonia e discórdia além da Europa, o que posteriormente trouxe problemas sérios, como as guerras fronteiriças entre as ex-colônias. Isso significa dizer que os princípios humanitários, como o "amor ao próximo", são dirigidos unicamente aos seus conterrâneos europeus; aos demais foi-lhes reservado o ódio, a violência e a desarmonia (Freud, 1927/1974b). Neste sentido, Freud chama atenção para o fato de que dificilmente uma só pulsão atua, uma vez que na sua face amorosa (Eros)

\footnotetext{
${ }^{3}$ Branquitude é conceituado por Schucman (2014) como lugar de privilégio e benefícios sociais de ser branco em uma sociedade racista. Não se trata de privilégios conquistados ou pré-determinados geneticamente e sim resultantes de domínios imperialistas, coloniais e escravocratas.
} 
ou erótica, agindo na preservação de espécie, pode atuar no sentido de dominar o outro ou um objeto com vista a deter posse e satisfação. Assim, o autor acredita que podemos atuar sob predisposições pulsionais para guerra e destruição, baseados em causas nobres, eróticas (Eros) e idealistas. Esses motivos podem ser vistos, por exemplo, nas guerras nacionalistas e na invasão aos outros países com justificativas de amor à pátria, e nas práticas de inquisição no seio da Europa. A colonização posterior à escravidão foram os atos por meio dos quais evidenciaram, também, essas formas de violências. A propósito, Fanon (2011/1956), em seu texto "Racismo e cultura”, considera que a colonização consiste em um tipo da violência marcada pela:

Exploração, torturas, razias, racismo, liquidações coletivas, opressão nacional, revezam-se em níveis diferentes para fazerem, literalmente, do autóctone um objeto nas mãos da nação ocupante. . . Este homem-objeto, sem meios de existir, sem razão de ser, é destruído no mais profundo da sua existência. O desejo de viver, de continuar, torna-se cada vez mais indeciso, cada vez mais fantasmático (Fanon, 2011, p. 277).

Esse fato constitui elo entre violência, capitalismo e nascimento da modernidade. Neste sentido, tanto para Fanon (2005) como para Césaire (1978), não é possível pensar a violência colonial esquivando-se do capitalismo, uma vez que os atos violentos perpetradas no período da colonização devem-se em grande parte à sustentação dos mercados financeiros, por meio da usurpação das matérias primas. Aliás, para Fanon (2005, p. 122), "a Europa é, literalmente, a criação do terceiro mundo. As riquezas que a sufocam são as que foram roubadas aos povos subdesenvolvidos . . . e fruto de milhões de escravos deportados". Por sua vez, na ótica de Mbembe (2018) e James (2010), sem os colonos e os escravizados, a modernidade e as burguesias inglesa e francesa não teriam existido. E Fanon acrescenta:

Durante séculos, os capitalistas se comportaram, no mundo "subdesenvolvido", como verdadeiros criminosos de guerra. As deportações, os massacres, o trabalho forçado, os escravismos foram os meios utilizados pelo capitalismo para aumentar as suas reservas de ouro e diamantes, suas riquezas, e para estabelecer a sua potência (Fanon, 2005, p. 121).
Por sua vez, em Por Que a Guerra, Freud e Einstein consideram que as grandes guerras perpetradas pela cultura ocidental sempre tiveram interesses capitalistas dissimulados, o que de certa forma favoreceu a expansão do poderio das grandes potências ocidentais (Freud, 1933/1976). Ora, propõe-se a seguinte questão: por que, mesmo com todos os instrumentos, os africanos escravizados não foram todos mortos à bala? Freud explica:

Matar um inimigo satisfazia uma inclinação instintual. Porém, a intenção de matar opor-se-ia a reflexão de que o inimigo podia ser utilizado na realização de serviços úteis, se fosse deixado vivo e num estado de imitação. Nesse caso, a violência do vencedor contentava-se com subjugar, em vez de matar, o vencido ... Foi este o início da ideia de poupar a vida de um inimigo, mas a partir daí o vencedor teve de contar com a oculta sede de vingança do adversário vencido e sacrificou uma parte da sua segurança (Freud, 1976, p. 247).

Nessa resposta à carta de Einstein, Freud demonstra que os europeus optaram por não matar os escravizados com o objetivo de aproveitar a força braçal desses em prol do desenvolvimento do capitalismo na sua forma mais perversa e desenfreada. Neste sentido, deixar o subjugado viver não constitui uma ação humanitária e sim desumanizada, visando manter os corpos objetificados e coisificados em nome do lucro e do capital. Percebe-se que a civilização, leia-se cultura ocidental, segundo Freud (1927/1974b), se propõe a controlar as pulsões agressivas para harmonia cultural nos níveis interno e mundial. Todavia, é a mesma que se protege contra as tendências instintivas de agressividade no próprio grupo de pertença, lançando as mesmas predisposições humanas aos outros. Pode-se falar de um pacto civilizacional do não uso da violência aos conterrâneos branco-europeus. Ou seja, uma paz social entre si, podendo, portanto, dirigir a barbárie e a destruição aos outros. A estes são reservados o altericídio, isto é, uma forma de alteridade que enclausura, violenta e nega o diferente não europeu (Mbembe, 2018).

A partir de Freud (1927/1974b), a barbárie do branco-ocidental sobre os outros povos fica mais evidenciada se recordarmos algumas monstruosidades cometidas no passado durante as migrações raciais como: as invasões dos hunos ou dos 
povos conhecidos como mongóis sob o comando de Gengis Khan e Tamerlão e nos horrores da recente guerra mundial. (Freud, 1927/1974b). Acrescenta-se a esses fatos as recordações dos horrores da escravidão africana e a colonização africana, embora Freud a não tenha citado, assim como grande número dos intelectuais europeus, o que se deve ao fato do Holocausto estar no centro dos exemplos das barbáries (Césaire, 1978).

No diálogo com Einstein no texto Por Que a Guerra?, Freud (1933/1976) fez algumas proposições que nos conduzem a reflexões sobre a violência e a guerra. Os dois pensadores concordaram que a guerra é constitutiva da civilização ocidental por se tratar de uma civilização que nasceu nas guerras contra si e contra as outras nações como as africanas, latinas e asiáticas. Os dois autores demonstraram sérias preocupações sobre como evitar a situação ameaçadora da guerra, apesar dos grandes avanços da civilização, frutos do progresso da racionalidade cientifica. Einstein destaca na carta que as grandes guerrilhas ocasionadas pela cultura europeia em justificativa da defesa da raça e da civilização foram favorecidas com a manutenção e o controle da igreja, da imprensa e das escolas no seu poderio, o que permitiu a influência e o domínio das massas a serviço da minoria dominante.

Para estes dois pensadores, algumas ideias podem até parecer insustentáveis, mas é importante destacar que elas assumem papeis importantes na união de um determinado povo. Por exemplo, a união em torno da exaltação da raça branca-europeia levou os europeus a cometerem atrocidades contra uma vasta gama de povos, como a escravidão e colonização africana, a colonização indígena e a invasão nas Américas. Do mesmo modo, a glorificação do arianismo provocou barbáries como Holocausto e as guerras mundiais dentro da própria cultura que se acha exemplo mundial da civilização. No passado, conforme afirma Freud (1933/1976), o mesmo aconteceu com pan-helenismo, em que os helênicos se entendiam superiores aos outros povos. Todos esses acontecimentos geraram as guerras, e por conseguinte, provocaram muitas mortes e outras formas de violência. Dito de outra forma, afirma Jurandir Freyre Costa:

O negro sabe que o branco criou a inquisição, o colonialismo, o imperialismo, o antissemitismo, o nazismo, o stalinismo e tantas outras formas de despotismo e opressão ao longo da história. $\mathrm{O}$ negro também sabe que o branco criou a escravidão e a pilhagem, as guerras e as destruições, dizimando milhares de vidas. O negro sabe igualmente que, hoje como ontem, pela fome de lucro e poder, o branco condenou e condena milhões e milhões de seres humanos à mais abjeta degradada miséria física e moral. O negro sabe tudo isso e, talvez, muito mais. Porém, a brancura transcende o branco. Eles indivíduo, povo, nação ou Estados brancos podem “enegrecer-se" (Costa, 1984, p. 106).

Percebe-se que a ideia do branco como sinônimo e modelo único do "bem", da "moral", da "ética" e dos "bons costumes" é hegemonizada e fortalecida pelo racismo, que coloca o negro subordinado aos ideais da branquitude. É preciso, portanto, que o branco se desloque desse lugar e o negro construa sua identidade sem ter o branco como aquele que espelha $o$ bem, pois este não é o exemplo de sujeito universal.

Uma outra questão levantada por Freud sobre a mesma ideia de cultura ou civilização é o uso da tecnologia, isto é, a racionalidade científica com finalidades para criações humanas caminha lado a lado com o uso da razão com fins da destruição e aniquilação dos outros (Freud, 1927/1974b). Em seu texto Reflexões para os Tempos de Guerra e Morte, Freud (1915/1974a) considera que a ciência perdeu a imparcialidade, buscando justificativas para a eliminação do inimigo. Para o psicanalista, a ciência antropológica, por exemplo, foi impulsionada a declarar que o indígena e o negro são inferiores e degenerados. Por sua vez, os psiquiatras fazem diagnósticos que levam a crer que este outro "exótico" padece de doença mental. Ou seja, uma vez que é inaceitável de ponto de vista moral matar o outro, precisou-se deslegitimá-lo para racionalmente justificar a sua aniquilação.

Ainda na mesma obra, Freud (1915/1974a) diz acreditar que a dita civilização branca-europeia encontre meios mais humanos de resolver os conflitos de interesses sem necessidade da guerra e da barbárie, uma vez que ela se exalta como raça superior e dominadora do mundo devido ao seu potencial técnico-científico e bélico. E, por esta razão, cabe-lhe liderar a espécie humana de todas as regiões do globo. Assim, esta cultura tentou introduzir os princípios morais $\mathrm{e}$ éticos que acredita serem fundamentais para a inserção em uma comunidade civilizada. Pactos que ela 
primeiro violou, na medida em que violentou e roubou as outras regiões em nome de tais preceitos e abusando do domínio técnico e bélico, o que favoreceu a subjugação e domesticação de outros povos. Ou melhor,

A guerra desperta dois tipos de sentimentos de desilusão: a baixa moralidade revelada externamente por Estado que, em suas relações internas, se intitulam guardiões dos padrões morais, e a brutalidade demonstrada pelos indivíduos, que enquanto participantes da mais alta civilização humana, não julgaríamos capazes de tal comportamento (Freud, 1915/1974a, p. 317).

Verifica-se, portanto, o fracasso moral de uma cultura que se dispõe a erradicar tendências instituais perigosas e más para o bem cultural. Assim, para Freud (1915/1974a), determinados atos primitivos ou retrógrados são desconsiderados pelo dito homem civilizado, porque acredita-se que a mente humana tem a capacidade básica da progressão. Somos incapazes, portanto, de pensar as ações mentais do ponto de vista de comportamentos regressivos. Porém, na realidade, a nossa mente não apenas atua nos níveis mais sublimes, mas também na capacidade de involução, isto é, no sentido mais primitivo da mente (Freud, 1915/1974a). No entanto, o que ocorre é que o homem moderno não admite estados mentais "incivilizados", como a aversão ao outro, o racismo antinegro e as guerras coloniais, situações em que o ser humano, principalmente o branco-europeu, se reduz ao mais baixo caráter civilizacional.

A outra matéria levantada pelo pai da psicanálise trata-se do fato da ampla maioria das pessoas serem retiradas do gozo e da satisfação das necessidades humanas básicas pela civilização que prometeu a elas a felicidade. Ou seja, a não distribuição equitativa dos recursos naturais, em alguns casos, pode acarretar a eclosão de pulsões hostis e/ou "contra-culturais" (Freud, 1927/1974a). Nota-se, portanto, que a civilização não só é violenta em seus princípios, mas também cria condições propiciais para a eclosão da violência e predisposições instintuais antissociais e/ou anticulturais. Freud resume o argumento da seguinte forma:

Dir-se-á que a característica das massas humanas aqui retratada, a qual se supõe provar que a coerção não pode ser dispensada no trabalho da civilização, constitui, ela própria, apenas o resultado de defeitos nos regulamentos culturais, falhas devido às quais os homens se tornarem amargurados, vingativos e inacessíveis. Gerações novas, que forem educadas com bondade, ensinadas a ter uma opinião elevada da razão, e que experimentaram os benefícios da civilização numa idade precoce, terão atitude diferente para com ela. Senti-la-ão como posse sua e estarão prontas, em seu benefício, a efetuar os sacrifícios referentes ao trabalho e à satisfação instintual que forem necessárias à sua preservação. Estarão aptas a fazê-lo sem coerção e pouco diferirão de seus líderes (Freud, 1915/1974a, pp. 18-19).

Freud pretende mostrar, com este argumento, que as classes sociais desprivilegiadas e menosprezadas pela civilização são excessivamente privadas de gozo, o que faz com que procurem se libertar da subjugação muitas vezes por meios considerados pela classe dominante como "anticulturais", "antissociais", "destruidoras da cultura" ou "anticivilizacionais”. Percebe-se, portanto, que a opressão das classes marginalizadas pode causar nelas um sentimento de hostilidade e insatisfação, que por conseguinte, se dirigem à cultura opressora. (Freud, 1927/1974b).

Na mesma ótica, Freud levanta outra questão em O Mal-Estar na Civilização (Freud, 1927/1974b). A pergunta diz respeito aos motivos pelos quais certas pessoas apresentam sentimentos hostis com relação à civilização que promete harmonizar o mundo em prol de um humanismo? Para este pensador, dois motivos merecem destaque: o primeiro deve-se ao fato do cristianismo, em nome da moral cristã, subjugar determinados povos (africanos, índios e outros), acreditando estar derrotando ao "paganismo". O segundo ponto se refere à invasão engendrada pelas grandes potências do ocidente a outros povos que, por meio das viagens de descoberta, entraram em contato com povos, nomeando-os primitivos e sem cultura. Na visão deste pensador, esta civilização condenou a si mesma, devido à insatisfação que causou historicamente a muitos povos, fruto da invasão e da rapinagem.

No contexto brasileiro, o psicanalista Joel Birman (2006) nomeia esta problemática de mal-estar na brasilidade. Para este autor, o mal estar da brasilidade tem a ver com a vergonha, não a culpa do parricídio. A culpa nesta acepção leva os sujeitos a almejarem uma figura de autoridade capaz de proporcionar a distribuição justa do gozo. No entanto, 
quando não se pode acreditar mais nisso, o que importa para a subjetividade é salvar a própria pele, isto é, garantir algum gozo próprio para si e ligar o "dane-se" geral para o gozo dos outros (Birman, 2006, p. 76).

Para este pensador, o mal-estar na brasilidade se deve à distribuição díspar do gozo, tendo em vista a adesão do Estado ao neoliberalismo, o que piorou o mal-estar já existente no Brasil, reflexo do passado sombrio da escravidão e do massacre dos povos indígenas. Assim, ao aderir ao capitalismo e a lógica patrimonialista, cujas consequências refletem na concentração do gozo, as autoridades estatais brasileiras acabam assumindo posturas agressivas e ostensivas. Estamos, portanto, diante de uma autêntica estrutura estatal genocida para com as classes populares. Genocídio este que gerou uma verdadeira guerra civil desorganizada, que tem como consequência direta o elevado índice da mortalidade da população negra e das classes mais miseráveis. Na visão de Birman (2006), violência, delinquência juvenil e criminalidade generalizada são patologias sociais, reflexos da não redistribuição de gozo que a classe branca dominante acumula historicamente por meio da violência e da exclusão.

Para Freud (1927/1974b), a civilização se propõe a utilizar Eros com intuito de reunir os seres humanos dispersos em famílias, depois em raças e em nações, construindo assim, uma grande unidade da humanidade. Reside na luta entre Eros e a morte, pulsão da vida e pulsão de morte e/ou da destruição, o princípio civilizador europeu que falhou, na medida em que não foi possível evitar pulsões com finalidades destrutivas dirigidas ao mundo exterior do Ocidente. O que significa dizer que a máxima “não matarás o outro" Levinas (2004) se aplica unicamente aos objetos e/ou sujeitos amados, restando aos não amados a destruição, a morte e a brutalidade. Esta é a verdadeira face da cultura ocidental-branca. Ressalta-se que o aforismo "não matarás" é o mesmo exaltado por um dos mandamentos do cristianismo, tratando-se de uma das mais valiosas riquezas deixadas pela herança cristã. Contudo, o mandamento cristão de "não matar próximo" e, sim, amá-lo, não vigorou no contato dos europeus com os outros povos, prevalecendo as invasões violentas (Levinas, 2004).

Neste sentido, as pulsões da morte e da vida podem atuar de forma mútua. Assim, a pulsão de morte amalgamada a Eros age agressivamente sobre o outro, visando preservar o ego. Ou seja, para evitar sua própria autodestruição, o ego dirige para o exterior sua agressão e ódio. Nota-se, portanto, que na sua versão da preservação da vida, "a pulsão de destruição, moderada e domada, e por assim, dizer, inibido em sua finalidade, deve, quando dirigida para objetos, proporcionar ao ego a satisfação de suas necessidades vitais e o controle sobre a sua natureza" (Freud, 1915/1974a, p. 144). Dito de outra forma, ao evitar me matar ou matar o meu objeto amado, dirijo morte a outrem. Na visão de Freud, isso se deve ao seguinte fato: "sempre possível unir um considerável número de pessoas no amor, enquanto sobrarem outras pessoas para receberem as manifestações da sua agressividade", estamos diante daquilo que o pai da psicanálise denomina de "narcisismo de pequenas diferenças” (Freud, 2006, p. 118). Percebe-se que os atos citados demonstram o quanto a ideia de "não matarás o outro" Levinas (2004), fundante da alteridade ocidental, não se aplica aos povos não europeus. Neste sentido, existe um pacto civilizacional que as elites brancas mundiais fazem entre si, concedendo maiores privilégios aos demais cidadãos brancos, ao mesmo tempo em os retira dos cidadãos negros, por exemplo, além de abdicaram da violência e destruição entre eles, por meio da adesão a esse pacto de irmandade. A mesma abdicação não se estende aos cidadãos negros, aos quais são dirigidos basicamente a violência, exclusão, negação e discriminação, fatores que atuam concomitantemente ao racismo.

O narcisismo de pequenas diferenças atua fortemente em desfavor dos grupos minoritários desde o início da civilização europeia, uma vez que os povos, as nações e as etnias se enfrentam de forma brutal em nome da preservação do gozo de si por meio da apreensão ostensiva do gozo do outro sujeito (Birman, 2006). Estratégia, por exemplo, que a Europa, em nome da expansão da civilização e da geração de felicidade, utilizou para roubar os outros povos de modo a sustentar o próprio gozo. O fim da escravidão no Brasil, por exemplo, fruto da pressão dos ativistas negros e/ou abolicionistas e as pressões internacionais, gerou logo em seguida um pacto de irmãos entre os brancos que ocorreu devido à não integração dos negros na sociedade brasileira após a abolição, assim como a recusa por parte dos brancos da reparação dos danos historicamente causados. Este fato criou uma gama de privilégios para a classe branca, e em contraposição, desvantagens e exclusão social da população 
negra que, por conseguinte, provocaram a favelização e as ondas de violência contra a população negra. Por outro lado, a democracia racial proposta por Gilberto Freyre (2003) se encaixa na lógica de um pacto de irmãos típica do narcisismo de pequenas diferenças, porém, às avessas. Neste caso, criou-se a ilusão de uma irmandade racial no Brasil, em que os negros e brancos convivem de forma harmônica e pacífica, tendo como objetivo subjugar a população negra, colocando-a na parte baixa da pirâmide social.

Percebe-se, portanto, que a história da humanidade está cheia de atrocidades e barbáries. Razão pela qual, para Freud (1933/1976), não há quem nasça em nossa época que não aprendeu nas escolas histórias da violência na construção da civilização. Por sua vez, James (2010) considera que foram os colonos branco-europeus que deram início as atrocidades, superando os outros povos no tocante à barbárie por ser uma civilização gerada e preparada na base da violência. Essa situação levou Adorno (1995), em Educação Após Auschwitz, repensar uma nova forma de educação diante das nossas vivências de Holocausto, da escravidão e de tantas outras invasões a outros povos. Com relação ao tráfico negreiro, apesar de todas essas violências, os judeus foram os dignos da admissão da culpa do branco-europeu e até de reparo dos danos causados pelo nazismo resultante da Segunda Guerra. Isso não foi feito aos ex-escravizados e às ex-colônias. No caso dos colonizados e escravizados africanos, os homens da cultura ocidente-cristão-branco-europeia em nenhum momento assumiram sentimento de culpa da violência, quiçá propuseram a restituição histórica em decorrência dos danos perpetrados durante as suas expedições. O que reforça a tese de Césaire ao afirmar que:

O que não perdoa a Hitler não é crime em si, o crime contra o homem, não é a humilhação do homem em si, é o crime contra o homem branco, a humilhação do homem branco e o ter aplicado à Europa os processos colonialistas a que até aqui só os árabes da Argélia, os "coolies" da índia e os negros de África estavam subordinados (Césaire, 1978, p. 19).

Na mesma ótica, Clastres (2004) considera que o termo genocídio, por exemplo, foi tipificado em 1946 no tribunal de Nuremberg, fazendo referência ao extermínio sistêmico perpetrado contra os judeus.
No entanto, a escravidão e o domínio colonial no século XIX contra os africanos e os outros povos não foram tachados como crime. Nota-se que os acontecimentos são caracterizados como crimes dependendo do quanto ferem o homem branco-europeu. $\mathrm{O}$ que explica a não criminalização e/ou a determinação do jugo colonial como potencial crime contra a humanidade. Acredito que isso se deve ao fato de as vítimas da violência colonial serem os outros não europeus, cujas vidas são tratadas como sendo não bem-aventuradas. Na mesma ótica, Delacampagne (2002, p. 131) considera que foi na era dos grandes "progressos" civilizatórios, a era das Luzes no século XVIII, que a escravidão teve os seus grandes avanços sem causar grandes indignações, o que levou o autor a levantar as seguintes questões provocativas: "seriam os progressos da razão incapazes de implicar o da justiça? Estariam a razão e o mal interligados?". O autor ressalta ainda que precisou esperar mais de dois séculos, concretamente só em 1945, após a ocorrência de diversas guerras e genocídios, para que estas atrocidades fossem compreendidas enquanto tal.

$\mathrm{Na}$ ótica fanoniana, a violência do colono sobre o colonizado não opera apenas por meios físicos, mas também no nível moral, uma vez que ele se coloca como detentor de valores éticos e morais impossíveis de serem assimilados pelos colonizados (Fanon, 2005). Isso, para o martinicano, é risonho, tendo em vista a violação dos princípios morais de que eles acreditam ser os guardiões. Aliás, como aponta Fanon, os valores que preexistiam no mundo do colonizado são infectados com valores defeituosos do ocidente branco-europeu: a pilhagem, a domesticação e o excesso de desejo pelo lucro. À semelhança de Freud, Fanon acredita que os atos violentos fazem parte do colonizador europeu e da sua própria cultura (Fanon, 2005). Ele afirma:

A violência com o qual se afirmou a supremacia dos valores brancos, a agressividade que impregnou o confronto vitorioso desses valores com os modos de vida ou de pensamento dos colonizados fazem com que, por uma justa contrapartida, o colonizado tenha um riso irônico quando se evocam diante dele esses valores (Fanon, 2005, p. 60).

Estes dois pensadores demonstraram a fragilidade dos valores fundantes do ocidente, isto é, não utilizar as pulsões agressivas para fins violentos e/ou 
destrutivos, assim como a máxima "não matarás o próximo" (Levinás, 2004). Pode-se acrescentar a isso, "não deixará o outro morrer de fome, logo dá-lhe o pão". Este último, para Fanon, é o valor primordial do colonizado. Ou seja:

Primeiro a terra: a terra que deve garantir o pão e, é claro, a dignidade. Mas, essa dignidade não tem nada a ver com a dignidade da "pessoa humana". Dessa pessoa humana ideal, ele nunca ouviu falar. O que o colonizado viu no seu solo é que se podia impunemente prendê-lo, espancá-lo, esfomeá-lo; e nunca nenhum professor de moral, nunca nenhum padre veio a receber pancadas em seu lugar nem dividir seu pão com ele. Para o colonizado, ser moralista é, muito concretamente, calar a arrogância do colono, quebrar a sua violência ostensiva, em uma palavra, expulsá-lo simplesmente da paisagem (Fanon, 2005, p. 60).

Argumentos que reforçam que o slogan moral de salvar os indígenas dos pecados e civilizá-los não passa de uma firula, porque de forma inequívoca a elevação moral dos outros não foi o verdadeiro motivo das expedições, e sim o enriquecimento dos mercados com matérias-primas furtadas. Assim, para Fanon (2005), as colônias, ou "ex-colônias", ao escreverem a história dos povos por elas subjugados, automaticamente escrevem também a própria. Ou seja, sua história diz respeito aos roubos, às violações da dignidade humana e à fome do outro (Fanon, 2005).

Do ponto de vista dos mecanismos de defesa, a perversidade da violência do colonizador é tão brutal que faz o colonizado acumular ira e agressividade. Assim, na impossibilidade de deslocá-lo para o colonizador, desloca-o contra o próprio irmão. Estamos diante da irracionalidade da violência, em que ela é deslocada do alvo; neste caso, encontra o mecanismo substitutivo do desejo acumulado da violência contra o colono (Costa, 1984), o que se manifesta, por exemplo, nas lutas étnicas, isto é, na autodestruição entre si dos colonizados. Vimos, assim, que "nos seus músculos, o colonizado está à espera. Não se pode dizer que ele seja inquieto, aterrorizado. Na verdade, ele está sempre pronto a abandonar o seu papel de caça e tornar caçador" (Fanon, 2005, p. 70).
Neste sentido, o ambiente colonial se caracteriza por um ambiente fértil para eclosão da violência e terror contra o violentador e o opressor. Razão pela qual Fanon denomina o colonialismo como uma máquina da mais pura desrazão, isto é, uma circunstância natural da violência que só é possível por meios violentos, que reforça a tese de Fanon da impossibilidade da luta colonial apenas por vias pacíficos (Rabaka, 2010). Dito de outra forma, é impossível a descolonização por meio da espera do bom senso ou benevolência pacifista dos colonos. Fanon salienta, ainda, que as massas coloniais perceberam de forma inequívoca que a liberdade só era possível pelo uso da força que os restava. Ou seja, uma vez enfraquecidos, famintos e sem técnicas, cabe aos homens do campo o uso da violência contra violência (Fanon, 2005). Por sua vez, James (2010, p. 22) afirma que "a violência e a ferocidade tornaram-se necessidades para a sobrevivência, e foram a violência e a ferocidade que sobreviveram.... Assim, os africanos, tornaram-se mais ferozes, ao longo dos séculos, à medida em que os métodos de coerção eram aperfeiçoados". Percebe-se, portanto, que a mutualidade da violência era a única relação possível entre o colono e o colonizado.

Por sua vez, Mbembe (2018) chama atenção para o fato de que a escravidão e a colonização são duas grandes ferocidades acometidas em nome da cultura ocidental. Acontecimentos que ocasionaram vítimas históricas da expansão europeia e das ações brutais perpetradas pelo mundo. Na visão de Mbembe, enquanto as potências europeias não se mobilizarem para reparar os danos terríveis causados em nome da "civilização", as vítimas continuarão exigindo deles uma postura restituidora. Aliás, Achille Mbembe, em uma entrevista concedida ao Novo Jornal, em 17 de janeiro de $2014^{4}$, considera que "a crítica da modernidade estará inacabada enquanto não compreendermos que o seu advento coincide com o princípio da definição da raça e da lenta transformação deste princípio em matriz privilegiada de dominação, ontem como hoje" (Mbembe, 2014, p. 6). Para Angela Davis (2018), o genocídio contra o povo negro desde a escravidão e a era colonial foram instituidores da violência do Estado do homem branco. O que significa dizer que a definição das hierarquias raciais e estratégias de subjugação são estruturantes na cultura ocidental.

${ }^{4}$ www.novojornal.co.ao 
Neste sentido, para Fanon (2005), os homens brutalizados querem apenas a reparação e restituição das suas humanidades. Ou seja, a restauração por parte de "aqueles que os mantiveram na escravidão durante séculos, é que o ajudem a reabilitar o homem, a fazer com que o homem triunfe por toda a parte, de uma vez por todas" (Fanon, 2005, p. 95). Isto não aconteceu, devido ao deslocamento do colonialismo para o neocolonialismo. Razão pela qual, na visão de Fanon, os branco-europeus procuram se justificar, por meio dos seus jornalistas que se deslocam nas terras africanas e/ou indígenas, criando a ilusão de que tudo vai mal ao pior desde que o colono deixou a África. A propósito, em seu texto, "Os jacobinos negros", James (2010, pp. 27-28) acredita que: "Há, e sempre haverá, os brancos que, envergonhados do comportamento dos seus antepassados, tentam, e tentarão provar, que a escravidão não era assim tão ruim, apesar de tudo, que seus males e s suas crueldades residiam no exagero propagandistas".

Isto explica os relatos sensacionalistas, espetaculares e desastrosos dos ambientes africanos, reforçando os estereótipos e preconceitos, que, por conseguinte, geram hostilidades, discriminações e até violências com relação a este povo.

\section{Considerações finais}

A violência colonial tem sido um dos focos do estudo de Fanon, assuntos tratados pelo autor na ótica psicanalítica e psiquiátrica, o que justifica o direcionamento deste trabalho para a psicanálise. Na acepção de Fanon, a violência assume uma perspectiva emancipadora, libertadora e constitutiva da subjetividade negada pelo colono. Segundo ele, "a violência assumida permite, ao mesmo tempo, aos desgarrados e proscritos do grupo voltar, reencontrar o seu lugar, reintegrar-se. A violência é assim compreendida como mediação real. Homem colonizada se liberta na e pela violência" (Fanon, 2004, p. 104).

De acordo com Rabaka (2010), apesar de algumas incompreensões, a obra de Fanon é de um humanismo revolucionário. Porém, a ele foram atribuídas algumas alcunhas, como "apóstolo da violência", o "profeta de uma violenta Revolução do Terceiro Mundo" e "o prisioneiro do ódio" (Rabaka, 2010, p. 168). Em uma das críticas, em seu texto Sobre a Violência, Hannah Arendt (1994, p. 14), por exemplo, não reconhece a perspectiva marxista de Fanon ao acreditar que este opta por uma luta colonial violenta por meio do proletariado sem classe e violenta. A pensadora afirma: "quem poderia chamar de marxista uma ideologia que depositou a sua fé em 'líderes sem classe', acredita que no proletariado a rebelião encontrará sua ponta de lança urbana", e está certo de que "gangsters iluminarão o caminho para o povo" .

Ora, Sartre aparece como um dos defensores das ideias engendradas por Fanon sobre a violência. No prefácio de Os Condenados da Terra, o filósofo demonstra que a violência pode se voltar contra a civilização que a fundou. Neste sentido, retorna ao polo oposto do direcionado. O que se deve ao fato de o colonizado não ter recurso pacífico para sobreviver, tendo em vista que deles foram retirados os critérios mínimos que dignifiquem e humanizem o ser. Assim afirma: "Na Argélia e em Angola os europeus são massacrados onde aparece ...É o terceiro tempo da violência: ela se volta contra nós, atinge-nos e, como das outras vezes, não compreendemos que é nossa" (Sartre, 2005, p. 13). Acrescenta, em outra página, o seguinte:

Essa violência irreprimível, ele o demonstra cabalmente, não é uma tempestade absurda nem a ressurreição de instintos selvagens e nem mesmo efeito de ressentimento; é o próprio homem que se recompõe. Sabíamos, creio eu, e esquecemos esta verdade: nenhuma suavidade apagará as marcas da violência; só a violência que pode destruí-las (Sartre, 2005, p. 14).

Com este último argumento, Sartre aponta a impossibilidade da não reciprocidade da violência no contexto colonial. Isso se deve ao fato de que, em um contexto de pura violência, o homem também se reconstitui por meio de respostas violentas. Assim, o sujeito se recompõe enquanto humano, detentor de valores inabaláveis, dentre os quais a liberdade e a dignidade.

Para Rabaka (2010), a obra do martinicano propõe debates que nos dias atuais são cruciais na luta pelos direitos fundamentais da dignidade humana: sexismo, racismo, emancipação dos povos subjugados, entre outros. Assim, revolução humanitária de Fanon está ao lado do subjugado e não do subjugador. Aliás, a defesa dos princípios humanistas deste pensador engloba a humanidade como um todo, o que inclui a luta contra o antissemitismo. Podemos constatar isso em Pele Negra, Máscaras Brancas, quando Fanon afirma que: 
O racismo colonial não difere dos outros racismos. O antissemitismo me atinge em plena carne, eu me emociono, esta contestação aterrorizante me debilita, negam-me a possibilidade de ser homem. Não posso deixar de ser solidário com o destino reservado a meu irmão. Cada um dos meus atos atinge o homem. Cada umas das minhas reticências, cada uma das minhas covardias revela o homem (Fanon, 2008. p. 87).

Percebe-se, portanto, uma preocupação coletiva de Fanon, na medida em que seu texto não focou apenas em questões que dizem respeito à África negra, lugar onde teve atuação mais direta (Rabaka, 2010). Ele é um homem além do seu tempo, na medida em que traz reflexões importantes no campo da psiquiatria sobre as consequências psíquicas do imperialismo, por meio da atmosfera violenta causada pelo colono. Fanon quer demonstrar na sua obra que a ideia do homem branco que acredita ser "universal" não se sustenta, na medida em que no mundo colonial escravista e no mundo indígena se revelou uma cultura nascida da imoralidade e da violação dos princípios civilizatórios. Acredita-se, portanto, que o homem branco-europeu, não é modelo universal e, sim, parte de um conjunto mais amplo da humanidade (Fanon, 2005, 2008).

Por sua vez, para Achille Mbembe, pensando conforme Frantz Fanon em relação à violência no contexto colonial, "a elevação em humanidade consiste, para o colonizado, em se transportar, por força própria, rumo a um lugar mais alto do que aquele que lhe foi consignado em função da raça ou em decorrência da sujeição" (Mbembe, 2018, p. 290). Para Mbembe, a grande reflexão que Fanon cria sobre a violência diz respeito às seguintes questões: de que forma a pulsão de autopreservação pode ser transformada em um ato político pleno? De que forma, em contextos de pura violência, a morte do colono é possível revirar em forma de contraviolência capaz de reinventar a vida? Como fazer desse contexto um ato emancipatório? Algumas dessas questões foram levantadas também por Freud na sua teoria das pulsões. Neste caso, as pulsões agressivas adormecidas podem ser desadormecidas em forma violenta, dirigindo-as ao colonizador. Isto porque, só por meio da contraviolência o colonizado é capaz de emancipar e significar a vida. Na visão de Mbembe, a negação da violência e, por conseguinte, a retribuição da violência contra o colono é uma forma de ressimbolizar. Dito de outra forma, as ações violentas do colonizado sobre o colono é uma forma de subjetivação. Neste sentido, diante do poderio militar do explorador "a única maneira de o colonizado voltar à vida é impor, pela violência, uma redefinição das modalidades da distribuição da morte" (Mbembe, 2018, p. 289).

Percebe-se, portanto, que a contraviolência do colonizado não visa apenas à descolonização. Trata-se também da necessidade de (des) patologização mental provocada pelas circunstâncias coloniais enfermas. A luta passa a ser entre assumir o risco e se fazer viver; não assumir o risco e deixar-se morrer, ser subjugado ou perder a humanidade. Por outro lado, a contraviolência também assume uma dimensão ética. $O$ ético aqui se refere àqueles atos violentos derivados das circunstâncias sociais e históricas, buscando atender as necessidades humanitárias dos colonizados. Na ótica de Mbembe, a violência fanoniana é uma forma de (re)-humanização por meio da elevação da humanidade. Assim, para o colonizado a práxis da violência objetiva restituir a dignidade do sujeito negro, racializado, objetificado e coisificado. (Mbembe, 2018)

Freud (1933/1976), alertou, em Por Que a Guerra?, que, ao não matar o subjugado, abre-se espaço para a vingança. Assim como afirmou Sartre no prefácio do livro de Fanon (2005): é o segundo tempo da violência, ao voltar contra si. Fatos que podem ser constatados na revolução de São Domingos (James, 2010) e na revolta dos Malês, em 25 de janeiro de 1835, (Reis, 2008), sem as quais a escravidão teria consequências piores do que as que ocorreram. Estas duas revoluções tiveram algo comum: ambas foram perpetrados pelos próprios escravizados. A haitiana, por exemplo, teve maior duração, doze anos (1791-1803), findando com a derrota dos soldados da monarquia francesa, alguns dos quais, participantes na Revolução Francesa. Há um paradoxo nessa questão: se o negro não se revolta, lhe é atribuído a passividade e docilidade "tola". Ao revoltar, lhe é imputado atributos violentos, muitas vezes animalescos. Ao branco é permitido tudo, inclusive as atitudes mais brutais, sem que isso o torne infra-humano.

Em Por Que a Guerra? (Freud, 1933/1976), Freud e Einsteintrouxeramaseguintereflexão:seaguerraseopõe à ideia da civilização, apesar de ser sua fundante, a luta deve ser entre a paze aguerra. Assim, nahumanidadenão existem apenas homens com fins destrutivos, mas também pacíficos, que são intolerantes à guerra. Contudo, até quando os pacifistas devem esperar que o restante da humanidade se torne pacifista? Pergunta que o psicanalista não soube responder. Neste sentido, acredito 
que Fanon teve razão ao afirmar que a luta colonial tinha que ser por todos os meios, inclusive os violentos, neste caso a violência emancipatória ou a "contraviolência", pois é a humanidade do homem que se encontra reduzida (Fanon, 2005; Mbembe, 2018; Rabaka, 2010), argumento que levou alguns pensadores a nomeá-lo injustamente de intelectual violento.

Buscou-se lançar neste trabalho duas acepções da violência: a primeira, diretamente ligada ao nascimento da civilização ocidente-cristã. A segunda ligada ao contexto colonial. E, porúltimo, discorreu-se sobre a imposição de um modelo cultural e da humanidade única, tendo a violência como princípio organizador. $\mathrm{O}$ artigo não pretende vangloriar a violência, mas apontar que ela é criada e sustentada pelos detentores do poder, o que significa dizer que os atos violentos não são prerrogativas dos oprimidos e, sim, do opressor. Ou seja, o violento é o imperialista, uma vez que o colonizado ou neocolonizado age de maneira "contraviolenta". Freud e Fanon foram felizes ao apontarem que a civilização ocidental nasceu no vício, que foi, em seguida, deslocado para outras civilizações em nome da ludibriadora moral. Este trabalho procurou também apontar as contradições da civilização que se predispõe a elevar a humanidade por meio da contenção das pulsões agressivas, mas que ao mesmo tempo desmanchou a dos outros, o que ocorreu na era colonial, escravocrata e ocorre nos dias atuais, em forma da tecnologia e da violência, sustentada pelo direito e lei.

\section{Referências}

Adorno, T. W. (1995). Educação após Auschwitz (W. L. Maar, Trad.). Paz e Terra

Arendt, H. (1994). Sobre a violência. Relume-Dumará.

Bird-Pollan, S. (2015). Hegel, Freud and Fanon: The dialectic of emancipation. Rowman \& Littlefield.

Birman, J. (2006). Arquivos do mal-estar e da resistência (2a ed.). Civilização Brasileira.

Césaire, Aimé (1978). Discurso sobre o colonialismo. Livraria Sá da Costa.

Costa, J. F. (1984). Violência e psicanálise. Graal.

Clastres, P. (2004). Arqueologia da violência: ensaio de antropologia política. Cosac Naify.

Davis, A. (2018). A liberdade é uma luta constante. Boitempo.

Delacampagne, C. (2002). História da Escravatura da Antiguidade aos nossos dias. Grafia.

Fanon, F. (2005). Os condenados da terra (E. Rocha \& L. Magalhães, Trads.). UFJF.

Fanon, F. (2008). Pele negra, máscaras brancas (R. Silveira, Trad.). EDUFBA.

Fanon, F. (2011). Racismo e cultura. In F. Fanon, Em defesa da revolução africana. Présence Africaine. (Obra original publicada em 1956)

Freud, S (2006). O Futuro de uma ilusão, o mal-estar na civilização e outros trabalhos. Edição Standard Brasileira das Obras Psicológicas Completas de Sigmund Freud, Vol. XXI Imago. (Obra original publicada em 1927)

Freud, S. (1974a). Reflexões para os tempos de guerra e morte (Edição Standard Brasileira das Obras Psicológicas Completas de Sigmund Freud, Vol. XIV). Imago. (Obra original publicada em 1915)

Freud, S. (1974b). O futuro de uma ilusão e o mal-estar na civilização e outros trabalhos (Edição Standard Brasileira das Obras Psicológicas Completas de Sigmund Freud, Vol. XXI). Imago. (Obra original publicada em 1927)

Freud, S. (1976). Por que a guerra. In S. Freud, Novas conferências introdutórias sobre Psicanálise e outros trabalhos 1932-1936) (Edição Standard das Obras Psicológicas Completas de Sigmund Freud, Vol. XXII, pp. 241-259). Imago. (Obra original publicada em 1933)

Freyre, G. (2003). Casa-grande e senzala (48a ed.). Global.

James, C. L. R. (2010). Os jacobinos negros: Toussaint L'Ouverture e a revolução de São Domingos. Boitempo.

Laplanche, J. (1993). Problemáticas I: A angústia (2a ed.). Martins Fontes.

Levinas, E. (2004). Entre nós: Ensaios sobre a alteridade. Vozes. 
Psicologia: Ciência e Profissão 2020 v. 40 (n.spe), e230245, 1-14.

Mbembe, A. (2014, 17 de janeiro). O mundo em estado de sítio. Novo Jornal, Mutamba: Sociedade Cultura e Lazer. Mbembe, A. (2018). Crítica da razão negra (S. Nascimento, Trad.). n-1.

Rabaka, R. (2010). Forms of Fanonism: Frantz Fanon's critical theory and the dialectics of decolonization. Lexington.

Reis, J. J. (2008). A Revolta dos malês em 1835. Universidade Federal da Bahia.

Rosendo, A. P. (2009). A reprodução: Elementos para uma teoria do sistema de ensino [Recensão de A reprodução: elementos para uma teoria do sistema de ensino, por P. Bourdieu e J.-P. Passeron]. LuSofia Press.

Said, E. W. (1995). Cultura e imperialismo (D. Bottmann, Trad.). Companhia das Letras.

Sartre, J.-P. (2005). Prefácio. In F. Fanon, Os condenados da terra (pp. 23-48). Universidade Federal de Juiz de Fora.

Schucman, L. V. (2014). Sim, nós somos racistas: estudo psicossocial da branquitude paulistana. Psicologia \& Sociedade, 26(1), 83-94. https://doi.org/10.1590/S0102-71822014000100010

\section{Lassana Danfá}

Psicólogo, bacharel em psicologia, mestre e doutorando em psicologia pela Universidade Federal de Pernambuco, Recife - PE. Brasil.

E-mail: delassanadanfa@hotmail.com

(1) https://orcid.org/0000-0002-9598-609X

\section{Financiamento CAPES}

Endereço para envio de correspondência:

Laboratório de Interação Social Humana (Labint). Avenida da Arquitetura, S/n, Cidade Universitária, CEP: 50740-550.

Recife - PE. Brasil.

Recebido 22/10/2019

Aceito 22/10/2019

Received 10/22/2019

Approved 10/22/2019

Recibido 22/10/2019

Aceptado 22/10/2019

Como citar: Danfá, L. (2020). Violência Civilizacional e Colonial no Olhar de Frantz Fanon e Sigmund Freud.

Psicologia: Ciência e Profissão, 40 (n.spe), 1-14. https://doi.org/10.1590/1982-3703003230245

How to cite: Danfá, L. (2020). Civilizatory and colonial violence from the standpoint of Frantz Fanon and Sigmund Freud. Psicologia: Ciência e Profissão, 40 (n.spe), 1-14. https://doi.org/10.1590/1982-3703003230245

Cómo citar: Danfá, L. (2020). Violencia civilizatoria y colonial bajo la mirada de Frantz Fanon y Sigmund Freud. Psicologia: Ciência e Profissão, 40 (n.spe), 1-14. https://doi.org/10.1590/1982-3703003230245 